\title{
Impact of protein hydrolysate biostimulants on growth of barley and wheat and their interaction with symbionts and pathogens
}

\author{
Christoph Stephan Schmidt ${ }^{1}$, Libor Mrnka ${ }^{1}$, Tomáš Frantík ${ }^{1}$, Martin Bárnet ${ }^{2}$, \\ Miroslav Vosátka ${ }^{1}$ and Eva Baldassarre Švecová ${ }^{1}$ \\ ${ }^{1}$ The Czech Academy of Sciences, Institute of Botany, Department of Mycorrhizal Symbioses, \\ Lesní 322, 252 43, Průhonice, Czech Republic \\ ${ }^{2}$ AGRA Group a.s., Tovární 201, 387 15, Střelské Hoštice, Czech Republic \\ e-mail: eva.svecova@ibot.cas.cz
}

\begin{abstract}
We compared the biostimulant effect of a novel chicken feather hydrolysate $(\mathrm{FH})$ and a reference protein hydrolysate $(\mathrm{RH})$ on barley and wheat in a pot experiment. Their interactions with arbuscular mycorrhizal fungi (AMF) and phosphorus $(\mathrm{P})$ supply were also addressed. All experimental factors influenced barley growth. Shoot height and biomass of barley were increased by FH and reduced by RH. AMF decreased barley biomass at high P-supply. In wheat, the biomass was slightly reduced by AMF while other factors had no significant effect. In the parallel field experiment, RH but not FH increased yield and grain size of barley, while there was no significant effect of either hydrolysate on wheat. Application time had no effect on hydrolysate efficacy. Both hydrolysates promoted severity of net blotch (Pyrenophora teres maculata) on barley in the pot experiment, but reduced it in field. FH promoted wheat root colonisation by AMF under low-P supply. Our results show limited transferability of pot results to field conditions and manifest complex interactions between hydrolysates, soil phosphorus, and plant symbionts and pathogens.
\end{abstract}

Key words: Hordeum vulgare, Triticum aestivum, arbuscular mycorrhizal fungi, soil phosphorus, Pyrenophora teres maculata

\section{Introduction}

In a world of a growing human population and diminishing resources, there is an urgent need to secure high crop yields concomitantly with the reduction of the environmental impact of conventional modern agriculture. One emerging strategy to achieve higher yields with reduced inputs of synthetic fertilisers and pesticides is the use of biostimulants for plant growth promotion. Biostimulants are defined as products stimulating plant nutrition processes independently of the product's nutrient content, with the sole aim of improving one or more of the following characteristics of the plant or the plant rhizosphere: nutrient use efficiency, tolerance to abiotic stress, quality traits, and availability of confined nutrients in the soil or rhizosphere (EU 2019). They are used in low quantities (Ertani et al. 2014) and pre-dominantly generated from waste materials (Halpern et al. 2015) thus being resourceefficient and fulfilling the demand of a circular economy.

Protein hydrolysates (PH) which contain amino acids and/or peptides are one key type of biostimulants (Kauffman et al. 2007). Exogenously applied amino acids (AA) and peptides are directly taken up by plants (Colla et al. 2015) and elicit plant responses as signal molecules (Forde and Lea 2007). They stimulate plant nutrient uptake, N-metabolism, C-metabolism and stress resistance (Calvo et al. 2014, Halpern et al. 2015, Colla et al. 2017) and can also trigger defence responses against pathogens (Cappelletti et al. 2017). PH are derived from both plant and animal waste materials and a number of commercial preparations based on $\mathrm{PH}$ is already available (Colla et al. 2015). An important but so far underutilised and problematic source of PH are chicken feathers. They are generated in huge quantities as they make up $5-10 \%$ of the chicken weight, yet they are difficult to degrade due to the rigid structure of their main component keratine (Stiborova et al. 2016). So far, only a minor proportion of feather waste is recycled via hydrolysis, although bans on classical disposal methods via landfill or incineration in some countries increase the urgency for sustainable recycling solutions (Stiborova et al. 2016). The biostimulating potential of chicken feather hydrolysates was apparent in a multitude of crops; their foliar application increased maize yield, nutrition and grain parameters (Tejada et al. 2018) and improved growth of wheat seedlings (Genç and Atici 2019) and lettuce (Sobucki et al. 2019).

Beneficial plant microbes represent another big group of biostimulants promoting plant growth and decreasing fertiliser and pesticide use. Arbuscular mycorrhizal fungi (AMF) form a particularly important group of these microbes. They colonise both endosphere and rhizosphere of their plant host forming characteristic structures 


\section{AGRICULTURAL AND FOOD SCIENCE}

C.S. Schmidt et al. (2020) 29: 177-193

(arbuscules and vesicles/spores) in the roots. From there they act as extended root systems taking up P, water and (micro)-nutrients in exchange of organic carbon (Parniske 2008). AMF play an essential role for P-nutrition of crops worldwide, especially under P-limiting conditions (Thompson et al. 1987) but they also improve micronutrient uptake of various crops (Lehmann and Rillig 2015). While their role in alleviating nutrient stress in plants is well established, their ability to modulate phytohormone balance and the defence response of plants has attracted greater attention only recently (Pozo and Azcón-Aguilar 2007, Fernández et al. 2014). Furthermore, stimulation of secondary metabolite production by AMF (Rydlová et al. 2016) can result in increased crop quality. AMF are present as natural compound of the soil microflora but particular strains of these fungi are also applied as commercial inocula especially in soils with low mycorrhizal inoculation potential (Vosátka et al. 2012). Although AMF inocula are often combined with other biostimulants in plant growth promoting preparations (Derkowska et al. 2017), the interaction of AMF with PH has been only marginally explored (Rouphael et al. 2017, Nafady et al. 2018). While synergies between microbial and non-microbial biostimulants have been reported, their mechanisms are not well understood. Both biostimulant groups modulate gene regulation, phytohormone balance, nutrient uptake, root system growth and plant secondary metabolism, especially metabolites involved in stress resistance (Halpern et al. 2015, Rouphael and Colla 2018). Thus, mechanisms of their synergic effects probably affect these areas. In spite of the fact that the benefit of AMF inocula is largely dependent on P nutrition of the host plants (Johnson et al. 1997), no studies exist on triple interaction of the factors P nutrition, AMF and hydrolysate so far. We aimed to fill this gap by conducting pot and field experiments with wheat and barley, which are the most important cereal crops in the EU (Leff et al. 2004). A positive effect of biostimulants based on amino acids on wheat yield was already shown by Popko et al. (2018).

In this study we compared the effect of a novel hydrolysate $(\mathrm{FH})$ prepared from chicken feathers by unique $\mathrm{CO}_{2}-$ assisted hydrolysis conducted under elevated pressure (Hanika et al. 2015) with a reference protein hydrolysate $(\mathrm{RH})$ on the growth and selected physiological parameters of the aforementioned crops. We aimed to elucidate the interaction between $\mathrm{P}$ nutrition, AMF inoculation and hydrolysate treatment in a tri-factorial pot experiment. Specifically we addressed the following questions: a) Do both hydrolysates promote growth of barley and wheat? b) Is the novel chicken feather hydrolysate more effective compared to the reference hydrolysate? c) Is there any interaction of the hydrolysates with AMF inoculation and phosphorus supply? We hypothesised that the benefit of the AMF inoculum would be low at high P-level and high at low P-level and that there would be a synergy between hydrolysates and AMF especially at low P-supply. Subsequently, we explored benefits of hydrolysates in a field experiment close to commercial conditions. As the effect of biostimulants application may depend on the growth stage of the crops we tested the effect of application timing (particularly at stem elongation /BBCH 31/, anthesis /BBCH 61/ and both). We hypothesised that earlier application would promote biomass accumulation and grain yield while the latter would promote grain yield and grain parameters such as $\mathrm{N}$-content and sedimentation index.

Natural infection with ascomycete Pyrenophora teres (imperfect stage Drechslera teres) occurred on barley in both the pot and the field experiments and offered an opportunity to study the effects of the treatment factors (hydrolysate, AMF inoculation, P-supply) on this disease. This allowed valuable insights into potential interactions between environmental factors (greenhouse vs. field), experimental treatments and disease development. The significance of exploration of the interaction with net blotch is underlined by the fact that this particular pathogen has emerged as a major disease in barley, causing yield losses of 10-40\% (Liu et al. 2011). We hypothesised that hydrolysate application may retard the fungal disease development due to an activation of plant immunity (Lachhab et al. 2014). We also expected AMF inoculation would suppress the disease spread (Veresoglou and Rillig 2012).

\section{Materials and methods}

\section{Crops and AMF inoculum}

The spring barley Hordeum vulgare 'Bojos' was used in the pot experiment, while 'Aktiv' was sown in the field experiment. Winter wheat Triticum aestivum 'Tobak' was used in both pot and field experiments. A mixture of Rhizophagus irregularis (strain Chomutov), Glomus claroideum (strain Chomutov), and Funneliformis mosseae (strain BEG95), maintained in the AMF stock culture collection of the Institute of Botany of the Czech Academy of Sciences was used as AMF inoculum in the pot experiment in 2017. The AMF inoculum consisted of a suspension containing colonised root segments, extra-radical mycelium and spores prepared from a mature maize culture with high mycorrhizal root colonisation $(>90 \%)$ and abundant sporulation. 


\section{AGRICULTURAL AND FOOD SCIENCE}

\section{Protein hydrolysates}

A novel feather protein hydrolysate (FH) was produced out of chicken feathers provided by the company Rabbit Trhový Štěpánov a.s. through $\mathrm{CO}_{2}$-assisted pressure hydrolysis conducted in the Institute of the Chemical Processes Fundamentals of the Czech Academy of Sciences, Czech Republic according to Hanika et al. (2015). The reference protein hydrolysate $(\mathrm{RH})$ derived from the tanning industry was provided by AGRA Group a.s. (Střelské Hoštice, Czech Republic).

FH contained $2.81 \mathrm{~g} \mathrm{l}^{-1}$ of peptides and $0.039 \mathrm{~g} \mathrm{l}^{-1}$ of free amino acids (AA) while RH (that was included as a positive control in the experiments) contained $330 \mathrm{~g} \mathrm{l}^{-1}$ of peptides and $381 \mathrm{~g} \mathrm{l}^{-1}$ of free amino acids (AA). The analysis of free AA composition of both hydrolysates was performed according to the ISO standards by the University of Chemistry and Technology, Prague, Czech Republic and is shown in the Table 1. Before application in the pot experiment, the concentration of both protein hydrolysates was adjusted to $0.28 \%$.

\begin{tabular}{lcc}
\multicolumn{3}{l}{ Table 1. Composition of the chicken feather hydrolysate (FH) and the reference hydrolysate (RH) } \\
used in the pot and the field experiments in 2017 & FH \\
\hline Amino acid & n.d. & 0.4 \\
\hline Asparagine (Asn) & 0.6 & 4.7 \\
Aspartic acid (Asp) & 10.1 & 2.0 \\
Phenylalanine (Phe) & 2.5 & 1.3 \\
Tyrosine (Tyr) & 25.9 & 2.8 \\
Iso-Leucine and Leucine (lle+Leu) & 4.0 & 0.7 \\
Methionine (Met) & 2.3 & 5.6 \\
Glutamic acid (Glu) & 18.1 & 1.9 \\
Valine (Val) & n.d. & 3.1 \\
Glutamine (Gln) & n.d. & 25.0 \\
Alanine (Ala) & 0.5 & 1.7 \\
Serine (Ser) & 24.0 & 31.1 \\
Glycine (Gly) & 0.4 & 5.6 \\
Proline (Pro) & 1.0 & 0.4 \\
Threonine (Thr) & n.d. & 0.3 \\
Histidine (His) & 8.0 & 1.0 \\
Lysine (Lys) & n.d. & 0.3 \\
Arginine (Arg) & n.d. & 0.6 \\
H-lysine (H-Lys) & 2.6 & 0.1 \\
Tryptophan (Trp) & n.d. & 11.7 \\
H-Pro & & not detected \\
\hline Amino acid concentration is expressed as a of the total amino acid content. n.d. & & \\
& &
\end{tabular}

\section{Set up of the pot experiment}

Factors in the pot experiment were crop (winter wheat 'Tobak', spring barley 'Bojos'), P-content of the substrate (low and high), presence and absence of mixed AMF inoculum, and repeated hydrolysate application during vegetative stage of growth (controls, $\mathrm{FH}$ and $\mathrm{RH}$ ). All treatments are summarised in Table 2. A mixture of river sand: zeolite : soil (4 : $4: 1$, volume ratio) with a low concentration of $\mathrm{P}$ (18 $\mathrm{mg} \mathrm{P} \mathrm{kg}^{-1} \mathrm{dry}$ substrate) was used. Final substrate parameters were as follows: $\mathrm{pH}(\mathrm{KCl}) 7.6,0.02 \% \mathrm{~N}, 0.23 \% \mathrm{C}, 17.9 / 147 \mathrm{mg} \mathrm{kg}^{-1} \mathrm{P}$ (exchangeable/total content), $5510 / 7451 \mathrm{mg} \mathrm{kg}^{-1} \mathrm{~K}$ (exchangeable/total content), 141/1929 mg kg-1 (exchangeable/total content), 5613/8256 mg $\mathrm{kg}^{-1} \mathrm{Ca}$ (exchangeable/total content). The substrate was gamma ( $25 \mathrm{kGy}$ ) sterilised in order to remove natural soil microflora including AMF. Conic two-litre pots (height $21 \mathrm{~cm}$, width at bottom $8 \times 8 \mathrm{~cm}$, width at the top $11 \times 11$ $\mathrm{cm}$ ) were filled with the substrate (substrate volume $1.8 \mathrm{I}$ ). In the high-P treatments, $8.25 \mathrm{ml}$ of $0.5 \mathrm{M}$ potassium phosphate buffer $\mathrm{pH} 7.0$ were applied per pot to elevate the P-concentration of the substrate from 18 to $82 \mathrm{mg} \mathrm{P}$ $\mathrm{kg}^{-1}$ dry substrate whereas the low-P treatment received no $P$. The substrate was moistened thoroughly by distilled $\mathrm{H}_{2} \mathrm{O}$ before AMF inoculum (20 mg per pot) was applied. Treatments without AMF (-AMF) received gamma-sterilised inoculum. Ten $\mathrm{ml}$ of bacterial filtrate were added per pot to restore the microbial flora in the sterilised soils. 


\section{AGRICULTURAL AND FOOD SCIENCE}

C.S. Schmidt et al. (2020) 29: 177-193

Twelve seeds of spring barley or winter wheat, respectively, were sown per pot and covered with a $2 \mathrm{~cm}$ layer of substrate. Pots were again thoroughly watered with distilled $\mathrm{H}_{2} \mathrm{O}$. Eight replicate pots were set up per treatment and arranged in a fully randomised block design in a greenhouse. Pots were surrounded by $35 \mathrm{~cm}$ high transparent plastic shields to avoid cross-contamination with AMF fungi. The experiment was set up on the $1^{\text {st }}$ June 2017 (maximum temperatures $26-32{ }^{\circ} \mathrm{C}$ ). Usual photosynthetic active radiation was around $230-310 \mu$ mol photons $\mathrm{m}^{-2} \mathrm{~s}^{-1}$ and no artificial illumination was used. Plants were thinned to 9 plants per pot two to four weeks after sowing. Modified Hoagland solution ( $5 \mathrm{mM} \mathrm{KNO}_{3}, 3 \mathrm{mM} \mathrm{Ca}\left(\mathrm{NO}_{3}\right)_{2} \cdot 4 \mathrm{H}_{2} \mathrm{O}, 2 \mathrm{mM} \mathrm{MgSO} \cdot 7 \mathrm{H}_{2} \mathrm{O}, 3 \mathrm{mM} \mathrm{NH}_{4} \mathrm{NO}_{3}, 0.0613$ $\mathrm{mM}$ FeNaEDTA, $0.05 \mathrm{mM} \mathrm{H}_{3} \mathrm{BO}_{3}, 0.01 \mathrm{mM} \mathrm{MnCl}_{2} \cdot 4 \mathrm{H}_{2} \mathrm{O}, 0.001 \mathrm{mM} \mathrm{ZnSO}_{4} \cdot 7 \mathrm{H}_{2} \mathrm{O}, 0.0004 \mathrm{mM} \mathrm{CuSO}_{4} \cdot 5 \mathrm{H}_{2} \mathrm{O}, 0.0005 \mathrm{mM}$ $\mathrm{Na}_{2} \mathrm{MoO} \cdot 2 \mathrm{H}_{2} \mathrm{O}, 0.00005 \mathrm{mM} \mathrm{CoSO}{ }_{4} \cdot 7 \mathrm{H}_{2} \mathrm{O}$ ) was applied at the dose of $25 \mathrm{ml}$ per pot 7 days after sowing and at the dose of $50 \mathrm{ml}$ per pot 28 days after sowing. Plants were regularly irrigated by deionized water.

Hydrolysates were used at a total concentration of $0.28 \%$ amino acids and peptides and amended with $0.025 \%$ TWEEN 20 for foliar application. Five $\mathrm{ml}$ per pot were finely misted onto the plant leaves, and plastic shields of pots were covered by transparent plastic foil for two days after each application to preserve high moisture; controls were sprayed with $5 \mathrm{ml}$ suspension of $0.025 \%$ TWEEN 20 . Hydrolysates were applied repeatedly $18,25,32$, 39 and 46 days after sowing. Shoot height was measured after $40 \mathrm{~d}$ growth and after $55 \mathrm{~d}$ growth (at harvest). At harvest, spring barley plants had reached the growth stage BBCH 49-57 (inflorescence emergence; Meyer 2018, based on Zadoks et al. 1974). Due to the spring sowing winter wheat plants did not develop inflorescences.

Table 2. Experimental treatments used in the pot experiment

\begin{tabular}{lcccc}
\hline Code & Hydrolysate & Phosphorus & AMF & Replicates (n) \\
\hline C_IP_nA & - & low & no & 8 \\
C_IP_A & - & low & yes & 8 \\
C_hP_nA & - & high & no & 8 \\
C_hP_A & - & high & yes & 8 \\
FH_IP_nA & FH & low & no & 8 \\
FH_IP_A & FH & low & yes & 8 \\
FH_hP_nA & FH & high & no & 8 \\
FH_hP_A & FH & high & yes & 8 \\
RH_IP_nA & RH & low & no & 8 \\
RH_IP_A & RH & low & yes & 8 \\
RH_hP_nA & RH & low & no & 8 \\
RH_hP_A & RH & low & yes & 8 \\
\hline
\end{tabular}

$\mathrm{FH}=$ chicken feather hydrolysate; $\mathrm{RH}=$ reference hydrolysate; both hydrolysates were applied $5 \mathrm{x}$ during the experimental period (one application: $5 \mathrm{ml}$ of $0.28 \%$ hydrolysate per pot; applications: $18,25,32,39$ and 46 days after sowing). AMF = inoculated mixture of 3 arbuscular mycorrhizal fungi (Rhizophagus irregularis, Glomus claroideum, and Funneliformes mosseae); phosphorus was applied either at low level (18 $\mathrm{mg} \mathrm{P} \mathrm{kg}^{-1}$ dry substrate) or high level ( $82 \mathrm{mg} \mathrm{P} \mathrm{kg}^{-1}$ dry substrate).

\section{Set up of the field experiment}

The field experiment was set up in Lukavec, Czech Republic (coordinates: 49 $33^{\prime} 21.2^{\prime \prime} \mathrm{N} 14^{\circ} 58^{\prime} 31.3^{\prime \prime} \mathrm{E}$ ). Treatments comprised controls and the variants with hydrolysates $\mathrm{FH}$ and $\mathrm{RH}$ applied according to the three different time schedules based on the growth stages of the crop (Meyer 2018): 1. Once at shoot elongation (BBCH 31: termed $\mathrm{FH} 31, \mathrm{RH} 31$, respectively); 2. once at flowering (BBCH 61: termed FH61 and RH61, respectively); 3. twice at $\mathrm{BBCH} 31$ and $\mathrm{BBCH} 61$ (termed $\mathrm{FH} 31+61$ and $\mathrm{RH} 31+61$, respectively). The list of treatments used in the experiment is shown in the Table 3 . The field design was a randomised block design; the four replicate blocks consisted of strips where replicates of the seven treatment combinations (consisting of $10 \times 1.5 \mathrm{~m}$ plots) were arranged linearly in a random manner (Suppl. Fig. 1). Soil parameters in the barley plots were as follows: medium heavy soil (sandy loam; according to agrochemical soil tests; soil categories based on the Law no. 275/1998 Sb.), $\mathrm{pH}$ 4.7, $71 \mathrm{mg} \mathrm{kg}^{-1} \mathrm{P}, 211 \mathrm{mg} \mathrm{kg}^{-1} \mathrm{~K}, 81 \mathrm{mg} \mathrm{kg}^{-1} \mathrm{Mg}, 940 \mathrm{mg} \mathrm{kg}^{-1} \mathrm{Ca}$. In the winter wheat plots, soil was light (loamy sand) with the following parameters: $\mathrm{pH}$ 5.7, $159 \mathrm{mg} \mathrm{kg}^{-1} \mathrm{P}, 239 \mathrm{mg} \mathrm{kg}^{-1} \mathrm{~K}, 103 \mathrm{mg} \mathrm{kg}^{-1} \mathrm{Mg}, 1310 \mathrm{mg} \mathrm{kg}^{-1}$ Ca. All given elemental contents are exchangeable (Mehlich III extracts). Spring barley was sown with a density of 300 seeds $\mathrm{m}^{-2}$ in March 2017 and winter wheat was sown with a density of 400 seeds $\mathrm{m}^{-2}$ in September 2016. 


\section{AGRICULTURAL AND FOOD SCIENCE}

C.S. Schmidt et al. (2020) 29: 177-193

FH (0.28\% peptides and AA, Table 1) was sprayed at an application rate of 120 I ha-1 and $\mathrm{RH}(36.8 \%$ peptides and AA; Table 1) was sprayed at an application rate of $2.5 \mathrm{I} \mathrm{ha-1}$; for spraying, hydrolysates were diluted to a final volume of $250 \mathrm{I} \mathrm{ha}^{-1}$ with water. Due to the limited quantity of available FH it was applied at a concentration of $0.13 \%$ while RH was applied at standard concentration used by the AGRA company regularly (0.37\%). Application during $\mathrm{BBCH} 31$ was done on the $26^{\text {th }}$ of May 2017 while application during BBCH 61 was performed at the $8^{\text {th }}$ of June 2017. Cultivation of the crops together with fertiliser and pesticide applications were done according to the standard cultivation manuals following the principles of Good experimental practice. In winter wheat, nitrogen fertilisers were applied three times: NPK 15-15-15 at a dose of $200 \mathrm{~kg} \mathrm{ha}^{-1}$ in September before sowing (corresponding to $30 \mathrm{~kg} \mathrm{~N} \mathrm{ha}^{-1}$ ), a mixture of ammonium nitrate with finely ground dolomite (LAD 27; HOKR s.r.o., Pardubice, Czech Republic) at a dose of $250 \mathrm{~kg} \mathrm{ha}^{-1}$ corresponding to $67.5 \mathrm{~kg} \mathrm{~N}^{-1}$ during March and a mixture of ammonium nitrate and finely ground limestone (LAV 27; LOVOCHEMIE a.S., Lovosice, Czech Republic) at a dose of $225 \mathrm{~kg} \mathrm{ha}^{-1}$ corresponding to $60.8 \mathrm{~kg} \mathrm{~N} \mathrm{ha}^{-1}$ during May. Post-emergence herbicide Bizon (active ingredients: penoxsulam, florasulam and diflufenican) was applied to wheat within the first month after sowing. In May, a herbicidal mixture of Attribute SG 70 (propoxycarbazone-sodium) and Mustang Forte (aminopyralid and florasulam) was applied followed by a mixture of the fungicide Adexar Plus (active ingredients epoxiconazole, fluxapyroxad, pyraclostrobin) and the insecticide Rapid (gamma-cyhalothrin). In spring barley a mixture of nitrogen fertilisers was applied once (NPK 15-15-15 at the dose $200 \mathrm{~kg} \mathrm{ha}^{-1}$ together with Urea Stabil (AGRA GROUP a.s., Střelské Hoštice, Czech Republic) at the dose of $100 \mathrm{~kg} \mathrm{ha}^{-1}$ (corresponding to $76 \mathrm{~kg} \mathrm{~N} \mathrm{ha}^{-1}$ before sowing in April). The post-emergence herbicide Pelicane Delta (active ingredients diflufenican and metsulfuron-methyl) with the soaking agent Dash HC was applied to barley in early May followed by the insecticide Rapid (gamma-cyhalothrin) in early June.

Table 3. List of experimental treatments used in the field experiment

\begin{tabular}{lllll}
\hline \multirow{2}{*}{ Code } & Treatment & Replicates $(\mathrm{n})$ & \multicolumn{2}{c}{ Protein hydrolysate application } \\
\cline { 4 - 5 } & & & Time (growth stage) & Dosage (\% AA+peptides; volume in I ha ${ }^{-1}$ ) \\
\hline Control & - & 4 & - & - \\
FH31 & FH & 4 & BBCH31 & $(0.13 ; 250)$ \\
FH61 & FH & 4 & BBCH61 & $(0.13 ; 250)$ \\
FH31+61 & FH & 4 & BBCH31+BBCH61 & $2 \times(0.13 ; 250)$ \\
RH31 & RH & 4 & BBCH31 & $(0.37 ; 250)$ \\
RH61 & RH & 4 & BBCH61 & $(0.37 ; 250)$ \\
RH31+61 & RH & 4 & BBCH31+BBCH61 & $2 \times(0.37 ; 250)$ \\
\hline
\end{tabular}

$\mathrm{FH}=$ novel chicken feathers-derived hydrolysate; $\mathrm{RH}$ = reference hydrolysate

\section{Disease assessment of SFNB (Pyrenophora teres maculata)}

The percentage leaf coverage by lesions of SFNB (Pyrenophora teres maculata) was assessed with the help of assessment sheets provided in the Bulletin OEPP/EPPO Bulletin (2012); disease severity was assessed at the flag leaf $(F)$, the $2^{\text {nd }}$ youngest leaf below the flag leaf $(F-1)$ and the $3^{\text {rd }}$ youngest leaf below the flag leaf $(F-2)$. In the greenhouse, all nine tillers of a pot (replicate) were assessed and the average severity per pot (replicate) was calculated for each leaf layer. In the field experiment, two tillers were assessed at six sampling spots evenly distributed across each experimental plot (for illustration see Suppl. Fig. 1) and the average severity per sampling spot was calculated within leaf layer. This was done on the $20^{\text {th }}$ of June 2017 at BBCH 49-57 in the pot experiment and on the $30^{\text {th }}$ of June 2017 at BBCH 73 (grain filling, early milk-ripe) in the field experiment. An earlier disease assessment at $\mathrm{BBCH} 36-39$ was done in the pot experiment on the $11^{\text {th }}$ of June 2017 . Since flag leaves were not visible in all plants at this stage, assessment was done for the whole replicate (pot). First the total of all leaves with their base within the plastic shields ( $35 \mathrm{~cm}$ height) were counted (leaves with their base above the shield were few and disease free) and the number of diseased leaves was determined. If the number of diseased leaves did not exceed 15 , all diseased leaves were assessed; otherwise 15 diseased leaves were assessed to calculate average disease severity in diseased leaves. Disease severity in each replicate pot was then calculated by multiplying average disease severity of diseased leaves with the proportion of diseased leaves to total number of leaves per replicate pot. 


\section{Measurement of photosynthetic pigments and of chlorophyll fluorescence}

Chlorophyll fluorescence (Quantum Yield [QY] of dark-adapted foliage = Fv/Fm) was measured with FluorPen FP100 (PSI, Photon Systems Instruments spol. s r.o., Drasov, Czech Republic). At least 3 leaves within each replicate pot were measured and the mean QY per pot was calculated. Photosynthetic pigments were measured spectrophotomectrically in dimethylformamide extract according to the procedure of Wellburn (1994).

\section{Yield parameters (Field experiment)}

Wheat and barley yield quality parameters (yield weight, moisture content, bulk density of the grain, $\mathrm{N}$-content, Zeleny sedimentation index, Hagberg falling number [HFN] and grain size distribution [> $2.8 \mathrm{~mm},>2.5 \mathrm{~mm},>2.2 \mathrm{~mm}]$ ) were determined by the Agricultural Regional Laboratory, Czech Republic, in compliance with the required standards.

\section{Assessment of root colonisation by symbiotic microorganisms}

Extent of root colonisation was determined by microscopy analysis after clearing the roots in $10 \% \mathrm{KOH}$ (w:v) for $40 \mathrm{~min}$ at $80^{\circ} \mathrm{C}$ and their subsequent staining with $0.05 \%$ trypan blue in lactoglycerol (Koske and Gemma 1989). Colonisation of fine roots ( $<2 \mathrm{~mm}$ in diameter) by AMF and endophytes was assessed according to the modified method after Dodd and Jeffries (1986). At least 150 visual fields per sample were inspected at 200x magnification with an Olympus BX-53 microscope. Colonisation of AMF in the field was not assessed as preliminary analysis indicated uniformly low (<7.5\%) colonisation rates (data not shown).

\section{Statistical evaluation}

Data were checked for normal distribution with Levene's test, and, if necessary arcsine-square-root or log-transformed. Three-way ANOVA was performed to assess significant effects of P-level, AMF-inoculation and hydrolysate application in the pot experiment for wheat and barley separately. In relevant cases, four-way ANOVA (fourth factor being crop) was used; values were expressed as percentages relative to the non-treated control (low $\mathrm{P},-\mathrm{AMF}$, no hydrolysate) in order to eliminate the impact of differences in absolute values between crops. If a significant effect of a particular treatment was found, Tukey HSD test was done to compare the treatments, and Dunnett's two sided test was performed to assess the effect of the treatment compared to the control. Whenever interactions were found, the effects of one factor within one level of other factors were assessed by split-data-ANOVA. In the field, disease assessment (where 6 groups of plants were assessed within each replicate plot) factorial nested ANOVA was done with the hydrolysate treatment, and leaf layer as the main factors while the factor block was nested within treatment and the factor "sampling spot" was nested within block. Two-factorial ANOVA was used to assess the effect of hydrolysate and spray regime within hydrolysate treatments (excluding the control) in the field experiment. If normal distribution could not be achieved, non-parametric Kruskall-Wallis or Mann-Whitney test were used. All statistical calculations were done with Statistica v. 12 (Dell Inc., Tulsa, U.S.A.).

\section{Results \\ The pot experiment}

\section{Effect of treatments on barley and wheat growth}

The treatments had a significant effect on growth and other measured parameters. Wheat and barley differed in their response to the reference hydrolysate (but not feather hydrolysate) in the number of biomass parameters relative to the control (total biomass, aboveground and belowground biomass). While no negative effect of the reference hydrolysate on plant biomass was observed in wheat, it was noticeable in barley (Fig. 1C). Wheat had a significantly higher ratio of belowground to aboveground biomass compared to barley irrespective of hydrolysate treatment (control, $\mathrm{FH}, \mathrm{RH}$ ). The opposite was true for the aboveground moisture where barley surpassed wheat. Three-way ANOVA with the factors hydrolysate treatment, P-level and AMF inoculation revealed far more significant treatment effects in barley than in wheat. Spring barley, but not winter wheat formed inflorescences at the time of harvest ( $55 \mathrm{~d}$ growth, BBCH 49-57). Shoot height of barley, measured at two dates ( $40 \mathrm{~d}$ and $55 \mathrm{~d}$ growth) was significantly affected by hydrolysate $(p=0.016)$ after $40 \mathrm{~d}$ growth (but not at harvest after $55 \mathrm{~d}$ ) and by P-level (Table 4, Fig. 1). All three factors (hydrolysate, P-level and AMF inoculation) significantly affected the aboveground biomass (shoots + spikes), spike biomass and root biomass of barley and there was an interaction of P-level and AMF for aboveground and spike biomass. Some parameters, such as root-to shoot ratio and quantum yield (QY) could not be analysed by multifactorial ANOVA in barley because variances were unequal, even after data transformation and thus they are not presented in Table 4. 
AMF inoculation resulted in significantly increased chlorophyll a/ chlorophyll b ratio in AMF inoculated barley and significantly increased QY in barley (Suppl. Table 1) indicating putatively greater photosynthetic efficacy. There was a three-way-interaction in QY among all tested factors (hydrolysate, P-level, AMF) in wheat (Table 4). When the effect of hydrolysate was analysed within P-level and AMF combinations, QY was significantly increased in wheat by both hydrolysates compared to controls but only at high P-level in the absence of AMF (Suppl. Fig. 2). No such effect was detected in barley.

Table 4. Effects of hydrolysate treatment $(\mathrm{H})$, P-level and AMF inoculation on growth parameters of spring barley and winter wheat in the pot experiment: $p$-values. Plants were harvested at $\mathrm{BBCH} 49$ (50-57) after $55 \mathrm{~d}$ growth.

\begin{tabular}{|c|c|c|c|c|c|c|c|c|c|c|}
\hline & Crop & S40 & $\mathrm{SH}$ & Shoot DW & Spike DW & AG DW & Root DW & Total DW & R/Sratio & QY \\
\hline \multirow[t]{2}{*}{$\mathrm{H}$} & barley & 0.016 & n.s. & 0.011 & 0.043 & 0.007 & 0.008 & 0.001 & - & - \\
\hline & wheat & n.s. & n.s. & n.s. & - & n.s. & n.s. & n.s. & n.s. & n.s. \\
\hline \multirow[t]{2}{*}{ P-level } & barley & 0.0498 & 0.001 & $<0.001$ & 0.046 & $<0.001$ & 0.023 & $<0.001$ & - & - \\
\hline & wheat & 0.024 & n.s. & n.s. & - & n.s. & n.s. & n.s. & n.s. & n.s. \\
\hline \multirow[t]{2}{*}{ AMF } & barley & n.s. & n.s. & n.s. & $<0.001$ & 0.031 & 0.014 & 0.009 & - & - \\
\hline & wheat & n.s. & 0.015 & $<0.001$ & - & $<0.001$ & $<0.001$ & $<0.001$ & $<0.001$ & n.s. \\
\hline \multirow[t]{2}{*}{$H^{*} \mathrm{P}$} & barley & n.s. & n.s. & n.s. & n.s. & n.s. & n.s. & n.s. & - & - \\
\hline & wheat & n.s. & n.s. & n.s. & - & n.s. & n.s. & n.s. & n.s. & n.s. \\
\hline \multirow[t]{2}{*}{$\mathrm{H}^{*} \mathrm{AMF}$} & barley & n.s. & 0.039 & n.s. & n.s. & n.s. & n.s. & n.s. & - & - \\
\hline & wheat & n.s. & n.s. & n.s. & - & n.s. & n.s. & n.s. & n.s. & n.s. \\
\hline \multirow[t]{2}{*}{$\mathrm{P} * \mathrm{AMF}$} & barley & n.s. & n.s. & n.s. & 0.005 & 0.032 & n.s. & n.s. & - & - \\
\hline & wheat & n.s. & n.s. & n.s. & - & n.s. & n.s. & n.s. & n.s. & n.s. \\
\hline \multirow[t]{2}{*}{$\mathrm{H}^{*} \mathrm{P}^{*} \mathrm{AMF}$} & barley & n.s. & n.s. & n.s. & n.s. & n.s. & n.s. & n.s. & - & - \\
\hline & wheat & n.s. & n.s. & n.s. & - & n.s. & n.s. & n.s. & n.s. & 0.033 \\
\hline
\end{tabular}

n.s. $=p>0.05 ; \mathrm{S} 40=$ shoot height $[\mathrm{cm}]$ after $40 \mathrm{~d}$ growth; $\mathrm{SH}=$ shoot height $[\mathrm{cm}]$ at harvest; $\mathrm{DW}=$ dry weight (constant weight at $65^{\circ} \mathrm{C}$ ) given in [g]; $A G=$ above-ground (shoots + spikes); $R / S=$ root to shoot ratio; $Q Y=$ fluorescence quantum yield of photosynthetic apparatus

Shoot height of barley after $40 \mathrm{~d}$ growth was slightly but significantly increased by application of FH (Fig. 1A). Although no longer significant, the same trend was also visible at harvest after $55 \mathrm{~d}$ growth (Fig. 1A, Suppl. Table 2). Increased P-supply reduced shoot height, especially in the presence of AMF (Fig. 1B). The positive effect of FH on shoot height was significant only in treatments with no AMF inoculation and average shoot height was not increased at all by hydrolysate treatments in the variants with high P-level and AMF inoculation, where shoot height was significantly lower compared to other P-AMF treatment combinations (Fig. 1B, Suppl. Fig. 3).

Hydrolysate application significantly affected all biomass parameters of barley, i.e. root DW, shoot DW and spike DW, aboveground DW (shoots including spikes) and total DW (Fig. 1C). Root DW, Shoot DW and spike DW were significantly increased by $\mathrm{FH}$ compared to $\mathrm{RH}$. The biomass of the control treatment was intermediate between the FH treatment (having the highest biomass) and the $\mathrm{RH}$ treatment (having the lowest biomass). This was true for all analysed plant parts, i.e. roots, shoots and spikes. No significant difference of either hydrolysate treatment compared to controls was detected except for the negative effect of RH on total biomass. The biomass of the $\mathrm{FH}$ variant was significantly higher than that of the $\mathrm{RH}$ variant in all analysed plant parts (Fig. 1C, Suppl. Table 2). Similar to shoot height, shoot and spike DW were lowest at high P-level in the presence of AMF; within high P-level shoot DW was significantly lowered by AMF, and within the AMF inoculated variants, shoot DW was significantly lowered by increase of $P$ supply (Fig. 1D). When the factor hydrolysate treatment was analysed within particular P-level $\times$ AMF combinations, there were mostly no significant effects of hydrolysates on biomass anymore, although the same trends still remained, particularly at low P-level and in the presence of AMF (Suppl. Fig. 4). AMF significantly decreased a number of biomass parameters in barley (Table 5).

Contrary to barley, there were very few significant effects of tested factors on growth parameters of wheat (Table 4). Hydrolysate treatment did not significantly affect any of the growth parameters although average shoot height and average biomass were slightly higher (103-104\% of control) after hydrolysate application (Suppl. Table 2). Shoot height after $40 \mathrm{~d}$ was significantly decreased at high P-supply, but at harvest (55 d growth) this difference had disappeared. AMF inoculation was the only factor significantly affecting a number of growth parameters in wheat. Root DW, shoot DW, total DW, root-to-shoot ratio were slightly decreased by AMF application (Table 5). 
Table 5. Effect of AMF inoculation on growth parameters of winter wheat and spring barley in the pot experiment. Shoot in barley refers to shoots without spikes; in root-to-shoot ratio, shoot+spikes were included; DW, dry weight.

\begin{tabular}{llccccc}
\hline & & shoot DW [g] & spikes DW $[\mathrm{g}]$ & root DW $[\mathrm{g}]$ & root-to-shoot ratio & total DW [g] \\
\hline Barley & no AMF & $3.4 \pm 0.04 \mathrm{x}$ & $1.1 \pm 0.03 \mathrm{x}$ & $1.2 \pm 0.03 \mathrm{x}$ & $0.28 \pm 0.006 \mathrm{x}$ & $5.7 \pm 0.08 \mathrm{x}$ \\
& AMF & $3.4 \pm 0.05 \mathrm{x}$ & $0.9 \pm 0.04 \mathrm{y}$ & $1.1 \pm 0.03 \mathrm{y}$ & $0.26 \pm 0.007 \mathrm{x}$ & $5.4 \pm 0.09 \mathrm{y}$ \\
\multirow{3}{*}{ Wheat } & no AMF & $5.0 \pm 0.06 \mathrm{a}$ & - & $3.5 \pm 0.10 \mathrm{a}$ & $0.7 \pm 0.02 \mathrm{a}$ & $8.6 \pm 0.14 \mathrm{a}$ \\
& AMF & $4.8 \pm 0.05 \mathrm{~b}$ & - & $2.8 \pm 0.07 \mathrm{~b}$ & $0.6 \pm 0.01 \mathrm{~b}$ & $7.7 \pm 0.10 \mathrm{~b}$ \\
\hline
\end{tabular}

Data represent means \pm SEM. Different letters indicate significant differences at $p<0.05$.
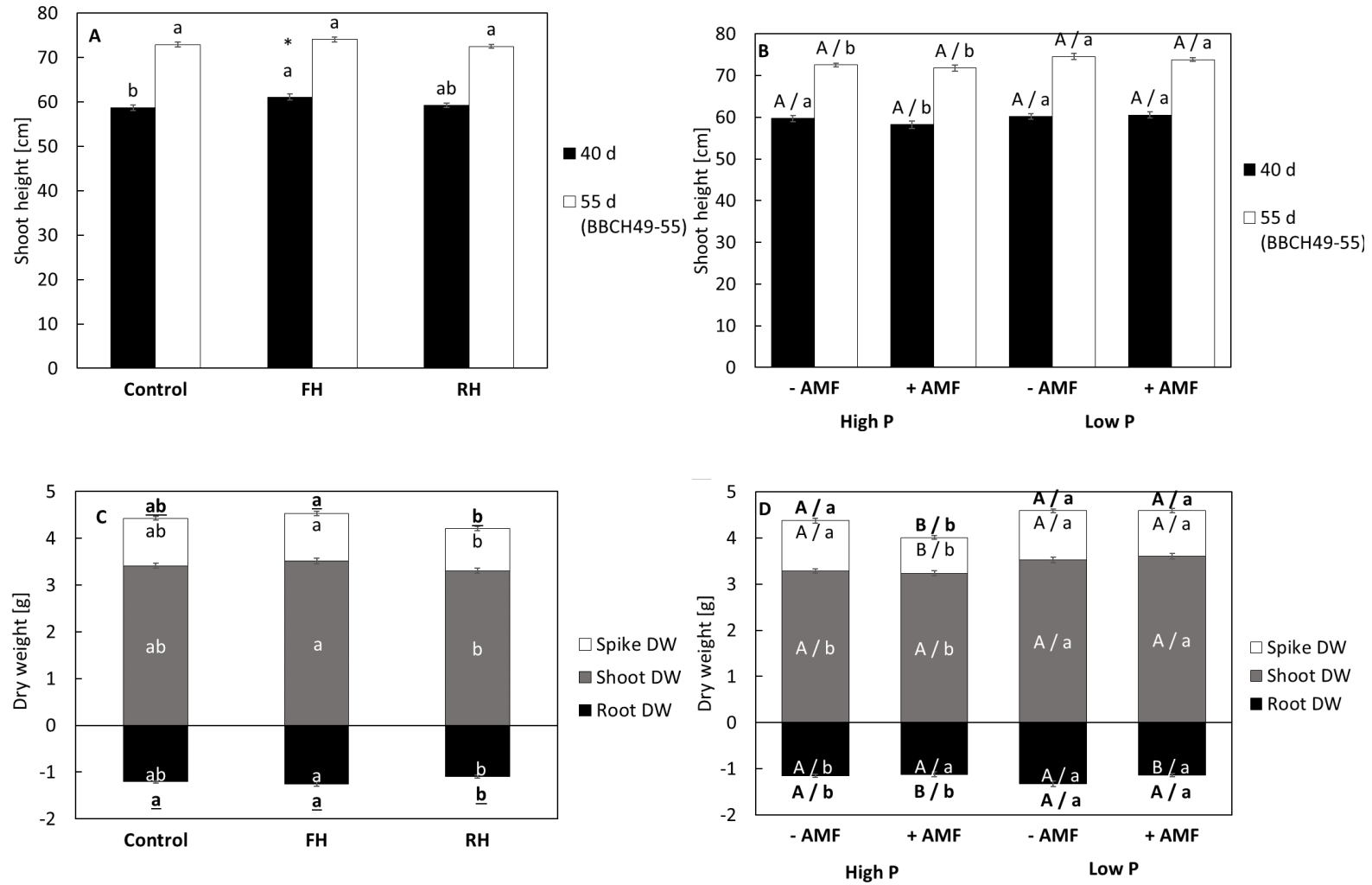

Fig. 1. Effect of experimental treatments on barley growth in the pot experiment. A,C: Effect of hydrolysates (FH, chicken feather hydrolysate; RH, reference hydrolysate) averaged over the factors "P-level" and "AMF". B,D: Effect of P-level and AMF averaged over the factor "hydrolysate". An asterisk indicates a significant effect of hydrolysate at $p<0.05\left({ }^{*}\right)$ compared to the corresponding control. Different letters indicate statistically significant $(p<0.05)$ differences between treatments. B and D: Capital letters indicate significant effects of AMF within given P-level, and small letters indicate significant effects of P-level within particular AMF-treatment. C and D: Small letters above bars indicate significant differences in DW of roots, shoots (excluding spikes) and spikes. Bold letters above bars indicate differences in the aboveground DW (shoots + spikes) and bold letters below bars indicate significant differences in total plant weight (shoots, spikes and roots). Below-ground biomass is shown as negative, above-ground biomass is shown as positive values. $\mathrm{BBCH}=$ growth stages according to Zadoks et al. 1974

\section{Effect of treatments on disease severity of SFNB (Pyrenophora teres maculata)}

Symptom development of SFNB ( $P$. teres maculata) set on during growth stage BBCH 30. We detected a highly significant effect of hydrolysate on severity of SFNB ( $p \leq 0.002$; Table 6$)$, a significant effect of P-supply $(p=0.038)$ and a highly significant interaction between P-level and AMF inoculation for the early disease assessment at BBCH 31-36 ( $p=0.009)$. There was no significant three-way interaction of all factors except for net blotch severity at $\mathrm{BBCH} 31-36$ and at $\mathrm{BBCH} 49-57$ for F-1 leaves $(p=0.04)$. For this reason, the hydrolysate effect (averaged over the factors $P$ and $A M F$ ) and the effect of $P$ and $A M F$ are presented in Figure 2. Averages for individual three-way treatment combination (hydrolysate $\times \mathrm{P} \times \mathrm{AMF}$ ) and the effect of hydrolysate treatment within each $\mathrm{P}$-level $\times \mathrm{AMF}$ combination are shown in Supplementary Figure 5 (net blotch severity in barley). 


\section{AGRICULTURAL AND FOOD SCIENCE}

C.S. Schmidt et al. (2020) 29: 177-193

Table 6. Effects of hydrolysate treatment (H), P-level and AMF inoculation on disease severity of net blotch in spring barley and leaf spots in winter wheat in the pot experiment

\begin{tabular}{|c|c|c|c|c|}
\hline & \multicolumn{2}{|c|}{ Barley, P. teres maculata } & \multirow[b]{3}{*}{$\mathrm{F}-1$} & \multirow{3}{*}{$\begin{array}{l}\text { Wheat, leaf spots } \\
\text { GS39 } \\
\text { All Leaves }\end{array}$} \\
\hline & $\mathrm{BBCH} 31-36$ & $\mathrm{BBCH} 49-57$ & & \\
\hline & Lower leaves & $\mathrm{F}-2$ & & \\
\hline H & $<0.0001$ & 0.002 & $<0.0001$ & n.s. \\
\hline P-level & 0.038 & n.s. & n.s. & 0.025 \\
\hline AMF & n.s. & n.s. & n.s. & 0.005 \\
\hline $\mathrm{H}^{*}$ P-level & n.s. & n.s. & n.s. & n.s. \\
\hline$H^{*}$ AMF & n.s. & n.s. & n.s. & n.s. \\
\hline P-level*AMF & 0.009 & n.s. & n.s. & n.s. \\
\hline $\mathrm{H}^{*} \mathrm{P}$-level*AMF & 0.040 & n.s. & 0.042 & n.s. \\
\hline Data transformation & $\operatorname{asin}($ sqrt) & - & $\operatorname{asin}($ sqrt) & $\operatorname{asin}($ sqrt) \\
\hline
\end{tabular}

Hydrolysate treatment significantly increased severity of net blotch (Fig. 2A). RH increased disease severity highly significantly $(p<0.001)$ already during an early stage (BBCH 31-36) whereas FH had no effect on net blotch (Fig. $2 \mathrm{~A}$ ) in this early stage. The outcome was the same in every factor combination (Suppl. Fig. 5). This changed close to harvest $(\mathrm{BBCH} 49-57)$ where severity of net blotch increased considerably from $3-12 \%$ to $15-25 \%$. At this stage, both hydrolysates had promoted disease severity in F-2 leaves significantly compared to the control. Averages for severity were higher in $\mathrm{FH}$-treated plants than in plants treated with $\mathrm{RH}$; in $\mathrm{F}$-1 leaves, $\mathrm{FH}$ was even the only hydrolysate significantly increasing net blotch severity (Fig. 2A). Although there was a significant effect of P-supply on disease severity of SFNB in the early stage (BBCH 32-36) and a significant interaction between P-supply and AMF inoculation ( $p=0.009$; Table 6), no significant differences showed up when P-levels were compared within one AMF-variant and when the effect of AMF-inoculation was analysed within one P-level (Fig. 2B). Generally, increased P-supply lowered SFNB severity. AMF inoculation decreased net blotch severity at high P-supply, but increased it under low P-regimes; disease severity was lowest at high P-supply in the presence of AMF. Similar trends were observable in the later growth stage BBCH 49-57 as well (Fig. 2B), although ANOVA showed no significant effects of $P$ and AMF (Table 6). When the effect of the factor hydrolysate was analysed within each factor combination of $\mathrm{P}$ and $\mathrm{AMF}$, the increase of net blotch severity by $\mathrm{RH}$ in the early growth stage $\mathrm{BBCH} 31-36$ was highly significant in each factor combination of P-level and AMF whereas close to harvest, $\mathrm{FH}$ increased net blotch severity in all $\mathrm{P} \times \mathrm{AMF}$ factor combinations except for the combination of high P-supply and AMF inoculation (high $\mathrm{P},+\mathrm{AMF}$ ), where disease severity was generally lowest (Suppl. Fig. 5).
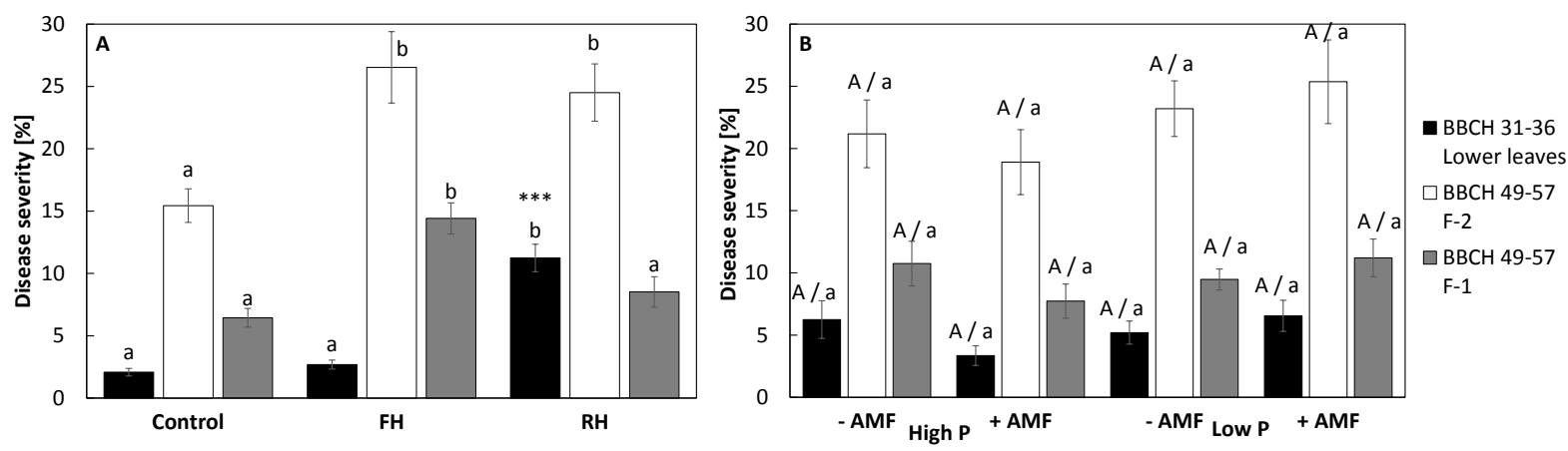

Fig. 2. Effect of experimental treatments on severity of net blotch (Pyrenophora teres maculata) of barley in the pot experiment. A: Effects of hydrolysates ( $\mathrm{FH}$, chicken feather hydrolysate; RH, reference hydrolysate) averaged over the factors "P-level" and "AMF". B: Effect of P-level and AMF averaged over the factor "hydrolysate". Asterisks indicate a significant effect of hydrolysate at $p<0.001$ $\left({ }^{* * *}\right)$ compared to the corresponding control according to Dunnett's test. Different letters indicate statistically significant $(p<0.05)$ differences among treatments. B: Large letters indicate significant effect of AMF within given P-level, and small letters indicate significant effect of P-level within particular AMF-treatment. BBCH = growth stages according to Zadoks et al. 1974 


\section{AGRICULTURAL AND FOOD SCIENCE}

\section{Effect of treatments on AMF colonisation}

Colonisation by AMF (and endophytic fungi) was only assessed in AMF-inoculated plants, since it was expected to be negligible in non-inoculated plants growing in the sterilised soil. Overall colonisation of fine roots by AMF was higher in wheat (16-41\%) than in barley (10-17\%) similarly to the root colonisation by endophytes (3-39\% in wheat, 6-23\% in barley). Hydrolysates had no major impact on colonisation of fine roots by AMF except for significant increase of AMF by FH application under low-P conditions in wheat. Higher AMF hyphal colonisation under low P-supply in FH-treated wheat was both apparent in increased frequencies of arbuscules as well as vesicles/ spores (data not shown). Interestingly, P-level did not influence AMF colonisation but rather endophytic colonisation which was highly augmented under low-P level in both crops (Fig. 3).

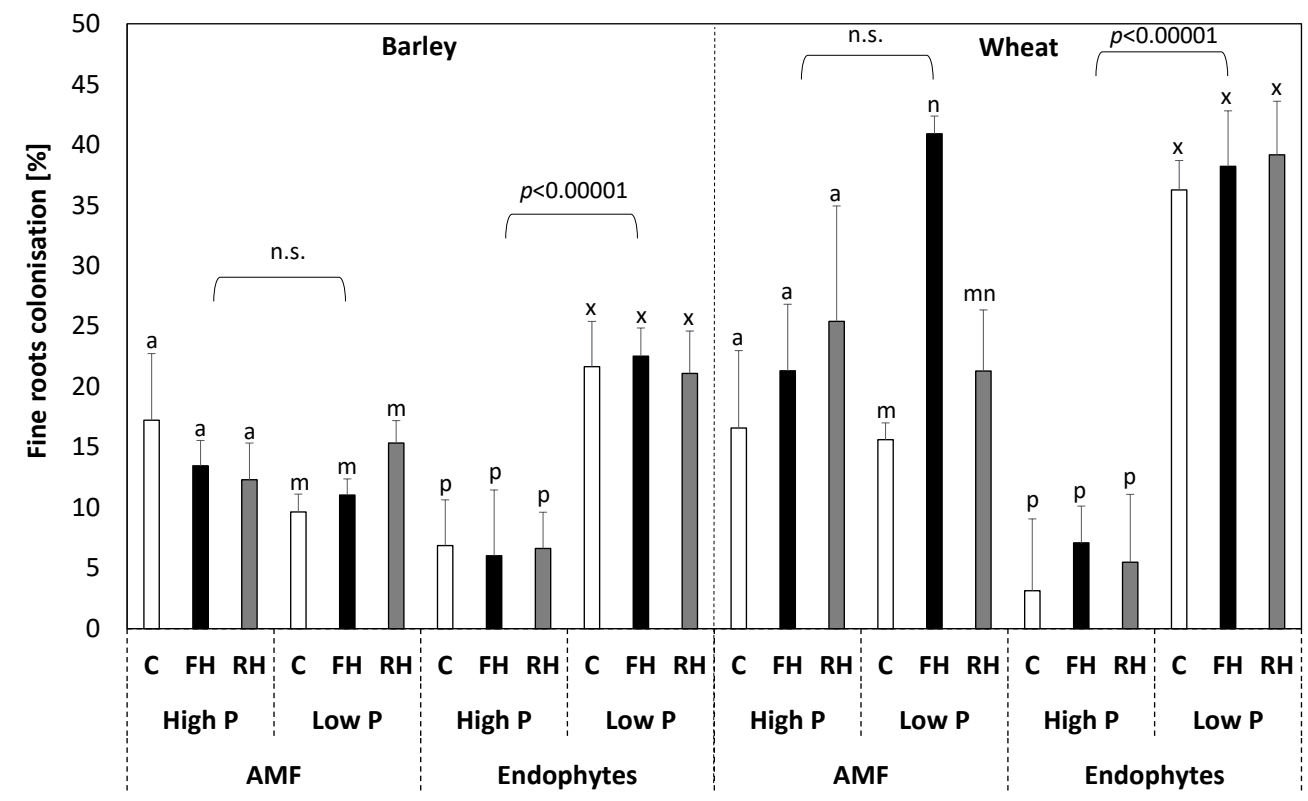

Fig 3. Effect of the experimental treatments on colonisation of fine roots by AMF and endophytic fungi, tested on barley and wheat in the pot experiment. Only treatments that received AMF inoculation were assessed both at high and low soil P-level and after leaf application of protein hydrolysates ( $\mathrm{FH}$, chicken feather hydrolysate; $\mathrm{RH}$, reference protein hydrolysate) or mock solution (C, corresponding controls). Different letters indicate statistical differences at the probability level of $p<0.05$ between hydrolysate treatments (separately within each combination of fungal groups and P-level). The impact of P-level assessed within given fungal group (AMF, endophytes) is indicated above the horizontal brackets.

\section{Effect of hydrolysate application on barley and wheat in the field Effect of protein hydrolysates on barley and wheat yield}

Yield was significantly higher in wheat than in barley but barley was more responsive to hydrolysate treatments than wheat (Table 7). $\mathrm{RH}$ increased the share of grain $>2.5 \mathrm{~mm}$ compared to FH but not to the control (when individual crops were tested this increase was significant in wheat but not in barley). There were no significant effects of hydrolysate application on yield, when individual treatment regimes (untreated control, FH31, FH61, FH31+61, $\mathrm{RH} 31, \mathrm{RH} 61, \mathrm{RH} 31+61$ ) were compared (Table 7), although treatments with RH showed generally higher yields (103-107\% of the control) in barley and all hydrolysate treatment regimes showed lower yields in wheat (93-96\% of the control). When hydrolysate treatments were compared without differentiating between application regimes (BBCH 31, BBCH 61, BBCH 31-61), RH resulted in significantly higher yields compared to FH in barley (Table 7). In two-way ANOVA with hydrolysate and application regime as factors (excluding the controls with no applications to achieve a factorial design), $\mathrm{RH}$ increased yields significantly compared to $\mathrm{FH}(p=0.02)$ whereas application regime had no effect. There was no interaction between the two factors.

In both barley and wheat, hydrolysate treatments and application regimes did not affect the grain quality parameters: bulk density of the grain, content of $\mathrm{N}$-containing substances, Zeleny index, grain size distribution and Hagberg falling number (HFN) when all seven treatments (control, FH31, FH61, FH31-61, RH31, RH61, RH31-61) were compared with each other and against the control (Suppl. Table 3). 
Table 7. Effect of protein hydrolysates on yield of spring barley and winter wheat in the field experiment

\begin{tabular}{lccccc}
\hline \multirow{2}{*}{ Treatment } & \multicolumn{2}{c}{ Spring barley } & & \multicolumn{2}{c}{ Winter wheat } \\
\cline { 2 - 3 } \cline { 5 - 6 } Single treatments & $\mathrm{t} \mathrm{ha}^{-1}$ & \% of control & & $\mathrm{t} \mathrm{ha}^{-1}$ & \% of control \\
Control & $5.4 \pm 0.20$ & 100 & & $9.4 \pm 0.28$ & 100 \\
FH 31 & $5.5 \pm 0.34$ & 101 & & $9.0 \pm 0.17$ & 96 \\
FH 31+61 & $5.2 \pm 0.23$ & 96 & & $8.8 \pm 0.38$ & 93 \\
FH 61 & $5.4 \pm 0.15$ & 100 & & $9.0 \pm 0.16$ & 96 \\
RH 31 & $5.8 \pm 0.07$ & 107 & & $9.0 \pm 0.39$ & 96 \\
RH 31+61 & $5.6 \pm 0.12$ & 103 & & $9.0 \pm 0.34$ & 96 \\
RH 61 & $5.9 \pm 0.12$ & 109 & & $8.8 \pm 0.38$ & 93 \\
Combined treatments & & & & \\
Control & $5.4 \pm 0.20$ ab & 100 & $9.4 \pm 0.28$ & 100 \\
FH & $5.4 \pm 0.14 \mathrm{~b}$ & 99 & $8.9 \pm 0.14$ & 95 \\
RH & $5.8 \pm 0.07 \mathrm{a}$ & 106 & $8.9 \pm 0.20$ & 95 \\
\hline
\end{tabular}

Hydrolysate treatments ( $\mathrm{FH}$ = chicken feather hydrolysate; $\mathrm{RH}=$ reference hydrolysate) were applied at different growth stages (BBCH31, BBCH61, and both BBCH 31 and BBCH 61). Significant differences $(p<0.05)$ are indicated by different letters. The codes of the treatments are explained in the Table 2.

In a two-factorial analysis with hydrolysate and application regime as factors (excluding controls), there was a significant effect of hydrolysate, but not of application regime. $\mathrm{RH}$ increased the grain size fraction $>2.5 \mathrm{~mm}$ compared to feather hydrolysate $\mathrm{FH}(86.45 \%$ vs $85.54 \%$, respectively: $p=0.031)$ and FH slightly increased the HFN compared to $\mathrm{RH}$ when applied at two times (354 vs. 333, respectively, when applied at $\mathrm{BBCH} 31$ and $\mathrm{BBCH} 61$; significance of the factor "hydrolysate" $p=0.046)$.

\section{Effect of treatments on disease severity of SFNB (Pyrenophora teres maculata)}

Disease severity of SFNB in barley was assessed in flag leaves, F-1 and F-2 leaves. Only the controls and the hydrolysate treatments with repeated applications $(\mathrm{BBCH} 31+61)$ were assessed as the greatest effect on disease development was expected here. Net blotch severity was significantly lower in the field compared to the pot experiment ( $<10 \%$ vs $6-30 \%$, respectively) although it was assessed at a later stage (BBCH 73 vs. BBCH $46-57$, respectively). There was a significant effect of leaf layer $(p<0.001)$ and hydrolysate treatment $(p<0.022)$ on severity of SNFB. As in the greenhouse, severity was higher in older leaf layers (F-2 > F-1 > F; Fig. 4A). Contrarily to outcomes of the pot experiment, both hydrolysates reduced disease severity of net blotch. RH caused a significant disease reduction in the flag leaf layer compared to the control ( $p=0.046$, Fig. $4 \mathrm{~A})$. When severity was averaged over all leaf layers, both hydrolysates reduced disease severity significantly (Fig. 4B).
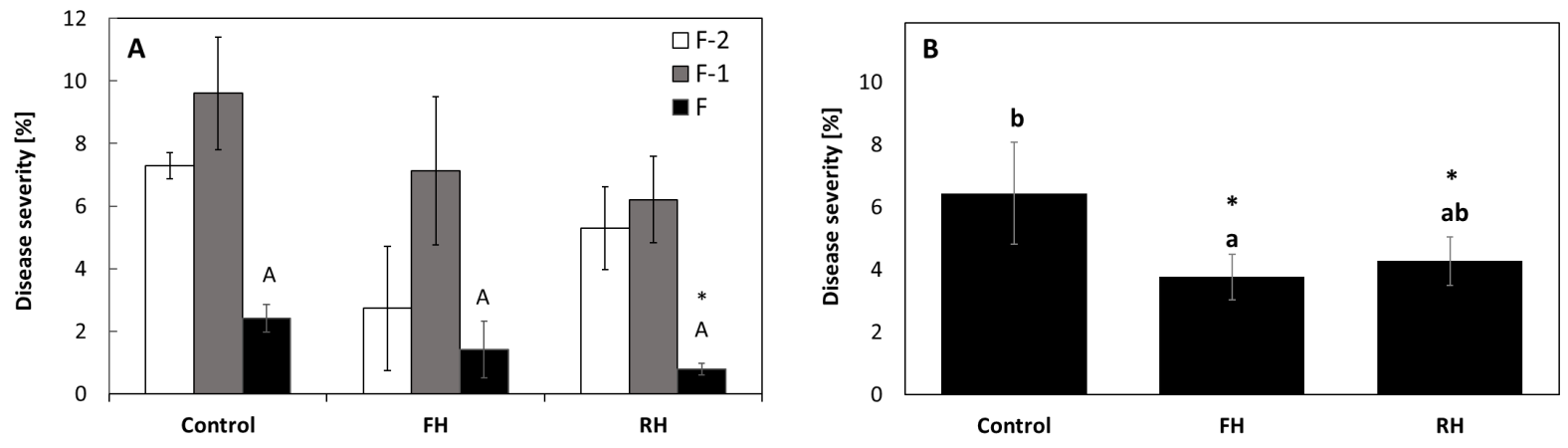

Fig. 4. Effect of repeated hydrolysate treatment on disease severity of the spot form of the net blotch of barley (Pyrenophora teres maculata) in the field experiment assessed at growth stage $\mathrm{BBCH} 73$. Treatments: $\mathrm{FH}$, chicken feather hydrolysate; $\mathrm{RH}$, reference hydrolysate; applied on BBCH31 and BBCH61. A: Disease severity in different leaf layers. B. Disease severity averaged over leaf layer. There was a significant effect of hydrolysate treatment $(p=0.022)$ and leaf layer $(p<0.001)$ on disease severity, but also significant effects of block $(p<0.001)$ and sampling spot within block $(p=0.044)$. Different letters indicate a significant difference according to Tukey HSD test at $p<0.05$. Asterisks indicate a significant difference to the control according to Dunnett's test at $p<0.05$. 


\section{AGRICULTURAL AND FOOD SCIENCE}

C.S. Schmidt et al. (2020) 29: 177-193

\section{Discussion}

Though we detected a number of significant effects caused by the experimental factors in this study, our postulated hypotheses were only partially met. Hydrolysate effects on crop growth and yield were confined to one of the tested cereal crops in this study (barley) and were rather modest in amplitude. Contrary to Popko et al. (2018) and Genç and Atici (2019) we could detect neither significant stimulation of wheat growth by the tested hydrolysates nor an increase in photosynthetic pigments. Although there was a trend towards increased shoot and root weight of wheat in the pot experiment, yields of wheat tended to be reduced in the field experiment. Several putative factors may explain the discrepancy between the results of the quoted studies and ours including experimental setup, cultivar selection, hydrolysate composition, dosage and timing of application. In barley, the only significant effect of the feather hydrolysate compared to the control in the pot experiment was a temporary increase in shoot height which might be attributed to auxine- and gibberelline-like effects of peptides and AA (Colla et al. 2014, Ertani et al. 2009). As for the effect of hydrolysates on plant biomass of barley, maximum biomass was accumulated in FH-treated plants and minimum in $\mathrm{RH}$-treated plants in the pot experiment whereas the opposite trend was observed in the field experiment. This may be explained by different dosage of hydrolysates in the field experiment where due to the lack of sufficient amount of feather hydrolysate it could only be applied at a dosage $2.8 x$ lower $(0.13 \%)$ compared to the reference hydrolysate (0.37\%). However, both Genç and Atici (2019) and Popko et al. (2018) observed significant growth promotion of wheat seedlings by chicken feather protein hydrolysate even at concentrations below $0.1 \%$. Plant growth promotion by hydrolysates is largely dependent on crop species and environmental conditions and none or only deleterious effects have been reported in a number of studies (Cerdán et al. 2009, Kunicki et al. 2010, Gajc-Wolska et al. 2012), even when commercial preparations were applied (Derkowska et al. 2017). The lack of a positive effect of RH on barley growth in the pot experiment might putatively be explained by its strong stimulation of SFNB already in early growth stages, whereas stimulation of the disease by FH occurred only in later stages of plant development, thus having a lesser effect on plant growth. However, disease stimulation is unlikely to be the only explanatory factor, as this was particularly significant in the high $\mathrm{P}+\mathrm{AMF}$ variants, where severity of net blotch was lowest.

Unexpectedly, P-fertilisation and AMF application did not have any significant positive effects on crop growth in our pot experiment. There was also no positive synergism between AMF application and PH application that manifested itself in increased plant growth as observed by Nafady et al. (2018) and as postulated in our hypotheses. However, feather hydrolysate augmented wheat root colonisation by arbuscular fungi including the frequency of arbuscules and vesicles/spores. Moreover we observed an increase of quantum yield by AMF in barley and enhanced QY by both hydrolysates in wheat in absence of AMF and at high P-level. Though this did not translate into growth promotion, it indicates how both biostimulants might interact with the plant. A positive effect of protein hydrolysates on the photosynthetic apparatus was also observed by Carillo et al. (2019), Genç and Atici (2019) and Sobucki et al. (2019). P-fertilisation and AMF inoculation slightly reduced crop growth, especially when they were combined. At high P-levels in the substrate, the host derives no benefit from improved $\mathrm{P}$ access via AMF whereas the burden of the carbon cost remains, turning the symbiotic relationship into a parasitic one (Johnson et al. 1997). Even under P-limitation where AMF increased uptake of $P$, a positive growth response to AMF inoculation can be often absent in pot experiments (Janoušková et al. 2009) due to other factors limiting growth such as nutrient depletion of the substrate, high root density or poor light. Cultivar selection can also significantly influence an output of a plant interaction with AMF (Hetrick et al. 1996). Significantly lower root-to-shoot ratio of both cereals treated with AMF may be due to AMF mycelia taking over the root function, especially in nutrient uptake (Smith and Read 2008).

The absence of any positive growth response to P-fertilisation could either be attributed to $\mathrm{P}$ being not limiting in our pot experiment or due to non-availability of the applied $\mathrm{P}$ to the plants. Although P-content in the nonfertilised substrate was $18 \mathrm{mg} \mathrm{P} \mathrm{kg}^{-1}$ dry substrate which is fairly below the threshold where soils are categorised as P-limiting (50 mg kg ${ }^{-1}$; Regulation no. 275/1998 Sb in the Czech Republic), barley and wheat plants did not display any symptoms of P-deficiency in the low P variants. P was applied dissolved in irrigation water and thus might have been subject to leaching. However, the irrigation was done carefully to minimize overflow of saucers and ensuing nutrient loss. Also, more than $40 \%$ of our substrate was composed of zeolite which is known to have considerable phosphorus retention capacity and there was a slight but significant decrease of plant growth and disease severity of net blotch in high P variants, especially in conjunction with AMF inoculation. Thus at least some added $P$ in high- $P$ treatments must have remained.

A strong stimulation of SFNB in the pot experiment and control of this disease in the field by PH was the most striking finding of this study, pointing towards a potential dependency of the hydrolysate effect on cultivar, dose 


\section{AGRICULTURAL AND FOOD SCIENCE}

C.S. Schmidt et al. (2020) 29: 177-193

and environmental conditions. Different barley cultivars were used in the pot experiment ('Bojos') and in the field ('Aktiv') with slightly different susceptibility to SFNB ('Bojos' being more susceptible). Thus the cultivars could contribute to the observed opposite effect of hydrolysates on SFNB spread. Moreover, overall hydrolysate dose was higher in the pot experiment than in the field experiment, as it was applied five times during the growth cycle vs $1-2$ times in the field. AA applied to plant surfaces can stimulate conidial germination (Blakeman and Brodie 1977) and mycelial growth (Schmidt et al. 2001) of necrotrophic pathogens. High air humidity resulting in a moist water film maintained on the leaves for two days after application prolonged their availability to germinating conidia, apart from generally creating a suitable environment for conidia germination and infection (van den Berg and Rossnagel 1990). Apart from direct effects on conidia, higher quantities of AA applied to the leaf surface can cause imbalances of intracellular AA composition in the plant and can make cells amenable to apoptosis (Bonner and Jensen 1997), thus facilitating the attack of necrotrophic pathogens such as SFNB (Able 2003). Therefore, higher concentration of amino acids and peptides in conjunction with high humidity may have stimulated infection in the pot experiment. Though we expected suppression of SFNB by arbuscular fungi as observed in other pathogens (Veresoglou and Rillig 2012), this occurred only at high P-supply while AMF augmented SFNB at low P-supply. A complex interaction between plant, AMF, P-level and pathogen (root rot nematode Meloidogyne hapla) was also observed by Cooper and Grandisons (1986). It was reported that AMF and P-level influence the transcription of chitinases and glucanases in the plant roots which may subsequently control intraradical fungal growth (Lambais and Mehdy 1998). As their study indicated a systemic effect on gene transcription, it is possible that AMF and P-level regulate genes with systemic range interacting with pathogens such as $P$. teres maculata. Such AMF-induced defence-related genes conferred resistance to pathogen infection in rice leaves (Campos-Soriano et al. 2012).

Overall doses of hydrolysates in the field, contrarily, were lower and the hydrolysate was applied under dry weather conditions. Thus, a moist PH-containing water film was possibly not maintained for long on the plants but AA and peptides were either taken up quickly by the leaves and those not taken up remained as a dry concentrated residue on the leaves after the spray film had dried (Pecha et al. 2011). Thus, stimulation of conidia was avoided. Under these conditions, the comparably weaker protective effect of the hydrolysates could unfold. Hydrolysates can induce plant resistance against pathogens (Lachhab et al. 2014, Cappelletti et al. 2017) and upregulate defence signalling pathways (Apone et al. 2010, Ertani et al. 2013, Lachhab et al. 2014). Glycine, a prevailing compound in the $\mathrm{FH}$ investigated in this study has been found to indirectly activate $\mathrm{Ca}^{2+}$ channels as a potentially first step in the signalling of the jasmonate defence pathway (Forde and Lea 2007, Scholz et al. 2014) involved in the defence against pathogenic fungi (Figueiredo et al. 2015, Thatcher et al. 2016).

Apart from direct effects of pathogen stimulation and defence induction, $\mathrm{PH}$ may also alter the local environment for plant pathogens by modulating the composition of the phyllosphere flora (Cappelletti et al. 2016) and increasing the proportion of antifungal isolates (Luziatelli et al. 2016, 2019). These processes are itself highly dependent on environmental conditions. Microbes are more effective competitors for AA than plants (Moe et al. 2013). Thus, hydrolysate compounds may be taken up by epiphytic microbes on the leaf surface before they enter the plant and induce defence reactions, especially under the humid conditions of the pot in our experiments.

Upregulation of defence responses might have also played a role in the reduction of disease severity of SFNB in barley inoculated with AMF under high P nutrition. AMF may stimulate defence-related signalling not only in roots (Pozo and Azcón-Aguilar 2007, Fernández et al. 2014), including roots of barley (Hause 2002), but also systematically in leaves upon foliar infection with necrotropic or biotrophic pathogens (Bruisson et al. 2016). Possibly this antifungal response might be stronger under high $\mathrm{P}$ nutrition, where AMF colonisation is no longer beneficial and cereals may limit its extent (Tang et al. 2016).

\section{Conclusions}

A number of studies reported plant growth promotion by protein hydrolysates (including feather hydrolysate) which was observable to a limited extent also in this study. Barley was shown to be more responsive to the tested hydrolysates than wheat. The reference hydrolysate promoted barley growth to a larger extent than feather hydrolysate but only in the field probably due to higher concentration of the former; in the pot experiment, a potential positive effect might have been impeded by concomitant promotion of net blotch. Grain quality parameters were influenced only marginally by the reference hydrolysate in wheat and application timing had no impact on either yield or grain parameters in both cereals. Contrary to our hypothesis, we detected no synergistic effects of hydrolysates and AMF inoculation on plant growth. Nevertheless, feather hydrolysate augmented AMF root colonisation as well as frequency of arbuscules and vesicles/spores in wheat pointing to roots as a place of 
interaction between the two biostimulants. The observed increase of quantum yield by AMF in barley and by both hydrolysates in wheat at low AMF and high P-level indicates that another potential mechanism of plant growth promotion might be the stimulation of the photosynthetic apparatus.

Importantly, our study showed, for hitherto unreported, a strong interaction between environmental conditions, biostimulants and disease. The same protein hydrolysate biostimulants either enhanced or inhibited development of net blotch in barley depending on the cultivar, dosage and environmental conditions. Further studies should elucidate the mechanisms which explain how these factors modulate the effect of biostimulants on symbionts and disease. Our study also indicated limited transferability of results obtained in the pot experiment to field conditions as the effects of tested hydrolysates on the growth of cereals and on the spread of disease were different in pots and the field.

\section{Acknowledgements}

We thank MSc. Dušan Kunc and RNDr. Helena Koblihová for skilful technical assistance. We are grateful to Ing. Olga Šolcová and Prof. Jiří Hanika from the Institute of Chemical Process Fundamentals of the Czech Academy of Sciences for providing the feather protein hydrolysate and to the team of Prof. Jana Hajšlová from the University of Chemistry and Technology, Prague, for the chemical analysis of the hydrolysates. We also highly appreciate implementation of the field experiment by Ing. Dana Jenčová from the Research unit at Lukavec, Czech Republic.

This project has received funding from the European Union's Horizon 2020 research and innovation programme under the Marie Sklodowska-Curie grant agreement No 749774. This article reflects only the author's view and the Research Executive Agency is not responsible for any use that may be made of the information it contains.

The financial support by the Technological Agency of the Czech Republic, project BIORAF (No. TE01020080), as well as long-term research development project RVO 67985939 (The Czech Academy of Sciences) is also greatly appreciated.

\section{References}

Able, A. 2003. Role of reactive oxygen species in the response of barley to necrotrophic pathogens. Protoplasma 221: 137-143. https://doi.org/10.1007/s00709-002-0064-1

Apone F., Tito, A., Carola, A., Arciello, S., Tortora, A., Filippini, L., Monoli, I., Cucchiara, M., Gibertoni, S., Chrispeels, M.J. \& Colucci, G. 2010. A mixture of peptides and sugars derived from plant cell walls increases plant defense responses to stress and attenuates ageing associated molecular changes in cultured skin cells. Journal of Biotechnology 145: 367-376. https://doi.org/10.1016/j.jbiotec.2009.11.021

Blakeman, J.P. \& Brodie, I.D.S. 1977. Competition for nutrients between epiphytic microorganisms and germination of spores of plant pathogens in beetroot leaves. Physiological Plant Pathology 10: 29-44. https://doi.org/10.1016/0048-4059(77)90005-4

Bonner, C.A. \& Jensen, R.A. 1997. Recognition of specific patterns of amino acid inhibition of growth in higher plants, uncomplicated by glutamine-reversible 'general amino acid inhibition'. Plant Science 130: 133-143. https://doi.org/10.1016/S0168-9452(97)00213-6

Bruisson, S., Maillot, P., Schellenbaum, P., Walter, B., Gindro, K. \& Deglène-Benbrahim, L. 2016. Arbuscular mycorrhizal symbiosis stimulates key genes of the phenylpropanoid biosynthesis and stilbenoid production in grapevine leaves in response to downy mildew and grey mould infection. Phytochemistry 131: 92-99. https://doi.org/10.1016/j.phytochem.2016.09.002

Bulletin OEPP/EPPO Bulletin 2012. Efficacy evaluation of fungicides. Foliar and ear diseases on cereals PP 1/26(4). EPPO Bulletin 42: 419-425. https://doi.org/10.1111/epp.2613

Calvo, P., Nelson, L. \& Kloepper, J.W. 2014. Agricultural uses of plant biostimulants. Plant Soil 383: 3-41.

https://doi.org/10.1007/s11104-014-2131-8

Campos-Soriano, L., García-Martínez, J. \& San Segundo, B. 2012. The arbuscular mycorrhizal symbiosis promotes the systemic induction of regulatory defence-related genes in rice leaves and confers resistance to pathogen infection. Molecular Plant Pathology 13: 579-592. https://doi.org/10.1111/j.1364-3703.2011.00773.x

Cappelletti, M., Perazzolli, M., Antonielli, L., Nesler, A., Torboli, E., Bianchedi, P.L., Pindo, M., Puopolo, G. \& Pertot, I. 2016. Leaf treatments with a protein-based resistance inducer partially modify phyllosphere microbial communities of grapevine. Frontiers in Plant Science 7: 1053. https://doi.org/10.3389/fpls.2016.01053

Cappelletti, M., Perazzolli, M., Nesler, A., Giovannini, O. \& Pertot, I. 2017. The Effect of Hydrolysis and Protein Source on the Efficacy of Protein Hydrolysates as Plant Resistance Inducers against Powdery Mildew. Journal of Bioprocessing and Biotechniques 7: 306. https://doi.org/10.4172/2155-9821.1000306

Carillo, P., Colla, G., Fusco, G.M., Dell'Aversana E., El-Nakhel, C., Giordano, M., Pannico, A., Cozzolino, E., Mori, M., Reynaud, H., Kyriacou, M.C., Cardarelli, M. \& Rouphael, Y. 2019. Morphological and Physiological Responses Induced by Protein HydrolysateBased Biostimulant and Nitrogen Rates in Greenhouse Spinach. Agronomy 9: 450. https://doi.org/10.3390/agronomy9080450 
Cerdán, M., Sánchez-Sánchez, A., Oliver, M., Juárez, M. \& Sánchez-Andreu, J.J. 2009. Effect of foliar and root applications of amino acids on iron uptake by tomato plants. Acta Horticulturae 830: 481-488. https://doi.org/10.17660/ActaHortic.2009.830.68

Colla, G., Rouphael, Y., Canaguier, R., Svecova, E. \& Cardarelli, M. 2014. Biostimulant action of a plant-derived protein hydrolysate produced through enzymatic hydrolysis. Frontiers in Plant Science 5: 448. https://doi.org/10.3389/fpls.2014.00448

Colla, G., Nardi, S., Cardarelli, M., Ertani, A., Lucini, L., Canaguier, R. \& Rouphael, Y. 2015. Protein hydrolysates as biostimulants in horticulture. Scientia Horticulturae 196: 28-38. https://doi.org/10.1016/j.scienta.2015.08.037

Colla, G., Hoagland, L., Ruzzi, M., Cardarelli, Bonini, P., Canaguier, R. \& Rouphael, Y. 2017. Biostimulant Action of Protein Hydrolysates: Unraveling Their Effects on Plant Physiology and Microbiome. Frontiers in Plant Science 8:2202. https://doi.org/10.3389/fpls.2017.02202

Cooper, K.M. \& Grandisons, G.S. 1986. Interaction of vesicular-arbuscular mycorrhizal fungi and root knot nematode on cultivars of tomato and white clover susceptible to Meloidogyne hapla. Annals of Applied Biology 108: 555-565. https://doi.org/10.1111/j.1744-7348.1986.tb01994.x

Derkowska, E., Paszt, L.S., Głuszek, S., Trzcińsk, P., Przybył, M. \& Frąc, M. 2017. Effects of treatment of apple trees with various bioproducts in tree growth and occurrence of mycorrhizal fungi in the roots. Acta Scientiarum Polonorum: Hortorum Cultus 16 : 75-83. https://doi.org/10.24326/asphc.2017.3.8

Dodd, J.C. \& Jeffries, P. 1986. Early development of vesicular-arbuscular mycorrhizas in autumn-sown cereals. Soil Biology and Biochemistry 18: 149-154. https://doi.org/10.1016/0038-0717(86)90019-2

Ertani, A., Pizzeghelio, D., Altissimo, A. \& Nardi, S. 2013. Use of meat hydrolyzate derived from tanning residues as plant biostimulant for hydroponically grown maize. Journal of Plant Nutrition and Soil Science 176: 287-296. https://doi.org/10.1002/jpln.201200020

Ertani, A., Cavani, L., Pizzeghello, D., Brandellero, E., Altissimo, A., Ciavatta, C. \& Nardi, S. 2009. Biostimulant activities of two protein hydrolysates on the growth and nitrogen metabolism in maize seedlings. Journal of Plant Nutrition and Soil Science 172 : 237-244. https://doi.org/10.1002/jpln.200800174

Ertani, A., Pizzeghello, D., Francioso, O., Sambo, P., Sanchez-Cortes, S. \& Nardi, S. 2014. Capsicum chinensis L. growth and nutraceutical properties are enhanced by biostimulants in a long-term period: chemical and metabolomics approaches. Frontiers in Plant Science 5: 1-12. https://doi.org/10.3389/fpls.2014.00375

EU 2019. Laying down rules on the making available on the market of EU fertilising products and amending Regulations (EC) No $1069 / 2009$ and (EC) No 1107/2009 and repealing Regulation (EC) No 2003/2003. https://eur-lex.europa.eu/legal-content/EN/ TXT/?uri=CELEX\%3A32019R1009. Cited 18 February 2020.

Fernández, I., Merlos, M., López-Ráez, J.A., Martínez-Medina, A., Ferrol, N., Azcón, C., Bonfante, P., Flors, V. \& Pozo, M.J. 2014. Defense related phytohormones regulation in arbuscular mycorrhizal symbioses depends on the partner genotypes. Journal of Chemical Ecology 40: 791-803. https://doi.org/10.1007/s10886-014-0473-6

Figueiredo, A., Monteiro, F. \& Sebastiana, M. 2015. First clues on a jasmonic acid role in grapevine resistance against the biotrophic fungus Plasmopara viticola. European Journal of Plant Pathology 142: 645-652. https://doi.org/10.1007/s10658-015-0634-7

Forde, B.G. \& Lea, P.J. 2007. Glutamate in plants: metabolism, regulation, and signalling. Journal of Experimental Botany 58: 23392358. https://doi.org/10.1093/jxb/erm121

Gajc-Wolska, J., Kowalczyk, K., Nowecka, M., Mazur, K. \& Metera, A. 2012. Effect of organic-mineral fertilizers on the yield and quality of Endive (Cichorium endivia L.). Acta Scientiarum Polonorum 11: 189-200.

Genç, E. \& Atici, O. 2019. Chicken feather protein hydrolysate as a biostimulant improves the growth of wheat seedlings by affecting biochemical and physiological parameters. Turkish Journal of Botany 43: 67-79. https://doi.org/10.3906/bot-1804-53

Halpern, M., Bar-Tal, A., Ofek, M., Minz, D., Muller, T. \& Yermiyahu, U. 2015. Chapter Two - The Use of Biostimulants for Enhancing Nutrient Uptake. Advances in Agronomy 130: 141-174. https://doi.org/10.1016/bs.agron.2014.10.001

Hanika, J., Šolcová, O. \& Kaštánek, P. 2015. Pressure hydrolysis of protein in waste of chicken cartilage and feathers in the presence of carbon dioxide. Proceedings of the 3rd International Conference on Chemical Technology, Mikulov, in April 13-15. p.435-438.

Hause, B., Mayer, W., Miersch, O., Kramell, R. \& Strack, D. 2002. Induction of jasmonate biosynthesis and arbuscular mycorrhizal barley roots. Journal of Plant Physiology 130: 1213-1220. https://doi.org/10.1104/pp.006007

Hetrick, B.A.D., Wilson, G.W.T. \& Todd, T.C. 1996. Mycorrhizal response in wheat cultivars: relationship to phosphorus. Canadian Journal of Botany 74: 19-25. https://doi.org/10.1139/b96-003

Janoušková, M., Seddas, P., Mrnka, L., van Tuinen, D., Dvořáčková, A., Tollot, M., Gianinazzi-Pearson, V., Vosátka, M. \& Gollotte, A. 2009. Development and activity of Glomus intraradices as affected by co-existence with Glomus claroideum in one root system. Mycorrhiza 19: 393-402. https://doi.org/10.1007/s00572-009-0243-4

Johnson, N.C., Graham, J.H. \& Smith, F.A. 1997. Functioning of mycorrhizal associations along the mutualism - parasitism continuum. New Phytologist 135: 575-585. https://doi.org/10.1046/j.1469-8137.1997.00729.x

Kauffman, G.L., Kneival, D.P. \& Watschke, T.L. 2007. Effects of biostimulant on the heat tolerance associated with photosynthetic capacity, membrane thermostability, and polyphenol production of perennial ryegrass. Crop Science 47: $261-267$. https://doi.org/10.2135/cropsci2006.03.0171

Koske, R.E. \& Gemma, J.N. 1989. A modified procedure for staining roots to detect VA mycorrhizas. Mycological Research 92: 486-488. https://doi.org/10.1016/S0953-7562(89)80195-9

Kunicki, E., Grabowska, A., Sękara, A. \& Wojciechowska, R. 2010. The effect of cultivar type, time of cultivation, and biostimulant treatment on the yield of spinach (Spinacia oleracea L). Folia Horticulturae 22: 9-13. https://doi.org/10.2478/fhort-2013-0153

Lachhab, N., Sanzani, S.M., Adrian, M., Chiltz, A., Balacey, S., Boselli, M., Ippolito, A. \& Benoit, P. 2014. Soybean and casein hydrolysates induce grapevine immune responses and resistance against Plasmopara viticola. Frontiers in Plant Science 5: 716. https://doi.org/10.3389/fpls.2014.00716 
Lambais, M.R. \& Mehdy, M.C. 1998. Spatial distribution of chitinases and $\beta$-1,3-glucanase transcripts in bean arbuscular mycorrhizal roots under low and high soil phosphate conditions. New Phytologist 140: 33-42. https://doi.org/10.1046/j.1469-8137.1998.00259.x Leff, B., Ramankutty, N. \& Foley, J.A. 2004. Geographic distribution of major crops across the world. Global Biogeochemical Cycles 18. https://doi.org/10.1029/2003GB002108

Lehmann, A. \& Rillig, M.C. 2015. Arbuscular mycorrhizal contribution to copper, manganese and iron nutrient concentrations in crops - A meta-analysis. Soil Biology and Biochemistry 81: 147-158. https://doi.org/10.1016/j.soilbio.2014.11.013

Liu, Z., Ellwood, S.R., Oliver, R.P. \& Friesen, T.L. 2011. Pyrenophora teres - profile of an increasingly damaging barley pathogen. Molecular Plant Pathology 12: 1-19. https://doi.org/10.1111/j.1364-3703.2010.00649.x

Luziatelli, F., Ficca, A.G., Colla, G., Baldassarre Švecová, E. \& Ruzzi, M. 2019. Foliar Application of Vegetal-Derived Bioactive Compounds Stimulates the Growth of Beneficial Bacteria and Enhances Microbiome Biodiversity in Lettuce. Frontiers in Plant Science. https://doi.org/10.3389/fpls.2019.00060

Luziatelli, F., Ficca, A.G., Colla, G., Svecova, E., \& Ruzzi, M. 2016. Effects of a protein hydrolysate-based biostimulant and two micronutrient based fertilizers on plant growth and epiphytic bacterial population of lettuce. Acta Horticulturae 1148: 43-48. https://doi.org/10.17660/ActaHortic.2016.1148.5

Meier, U. 2018. Growth stages of mono- and dicotyledonous plants: BBCH Monograph. Julius Kühn Institute (JKI). Quedlinburg. Open Agrar Repositorium. https://doi.org/10.5073/20180906-074619

Moe, L.A. 2013. Amino acids in the rhizosphere: from plants to microbes. American Journal of Botany 100: 1692-1705. https://doi.org/10.3732/ajb.1300033

Nafady, N.A., Hassan, E.A., Abd-Alla, M.H. \& Bagy, M.M.K. 2018. Effectiveness of eco-friendly arbuscular mycorrhizal fungi biofertilizer and bacterial feather hydrolysate in promoting growth of Vicia faba in sandy soil. Biocatalysis and Agricultural Biotechnology 16: 140-147. https://doi.org/10.1016/j.bcab.2018.07.024

Parniske, M. 2008. Arbuscular mycorrhiza: the mother of plant root endosymbioses. Nature Reviews Microbiology 6: 763-775. https://doi.org/10.1038/nrmicro1987

Pecha, J., Fürst, T., Kolomazník, K., Friebrová, V. \& Svoboda, P. 2011. Protein biostimulant foliar uptake modeling: The impact of climatic conditions. AIChE Journal 58: 2010-2019. https://doi.org/10.1002/aic.12739

Popko, M., Michalak, I., Wilk, R., Gramza, M., Chojnacka, K. \& Górecki, H. 2018. Effect of the New Plant Growth Biostimulants Based on Amino Acids on Yield and Grain Quality of Winter Wheat. Molecules 23. https://doi.org/10.3390/molecules23020470

Pozo, M.J. \& Azcón-Aguilar, C. 2007. Unravelling mycorrhiza-induced resistance. Current Opinion in Plant Biology 10: 393-398. https://doi.org/10.1016/j.pbi.2007.05.004

Rouphael Y., Cardarelli, M., Bonini, P. \& Colla, G. 2017. Synergistic action of a microbial-based biostimulant and a plant derived-protein hydrolysate enhances lettuce tolerance to alkalinity and salinity. Frontiers in Plant Science. https://doi.org/10.3389/fpls.2017.0013

Rouphael, Y. \& Colla, G. 2018. Synergistic Biostimulatory Action: Designing the Next Generation of Plant Biostimulants for Sustainable Agriculture. Frontiers in Plant Science 9:1655. https://doi.org/10.3389/fpls.2018.01655

Rydlová, J., Jelínková, M., Dušek, K., Dušková, E., Vosátka, M. \& Püschel, D. 2016. Arbuscular mycorrhiza differentially affects synthesis of essential oils in coriander and dill. Mycorrhiza 26: 123-131. https://doi.org/10.1007/s00572-015-0652-5

Schmidt, C.S., Lorenz, D. \& Wolf, G.A. 2001. Biological control of the grapevine dieback fungus Eutypa lata II: Influence of formulation additives and transposon mutagenesis on the antagonistic activity of Bacillus subtilis and Erwinia herbicola. Journal of Phytopathology 149: 437-445. https://doi.org/10.1046/j.1439-0434.2001.00656.x

Scholz, S.S., Vadassery, J., Heyer, M., Reichelt, M., Bender, K.W., Snedden, W.A., Boland, W. \& Mithöfer, A. 2014. Mutation of the Arabidopsis Calmodulin-Like Protein CML37 Deregulates the Jasmonate Pathway and Enhances Susceptibility to Herbivory. Molecular Plant 7: 1717-1726. https://doi.org/10.1093/mp/ssu102

Smith, S.E. \& Read, D. 2008. Mycorrhizal Symbiosis (Third edition). Academic Press. p. 1-787. https://doi.org/10.1016/B978-012370526-6.50002-7

Sobucki, L., Ramos, R.F., Gubiani, E., Brunetto, G., Kaiser, D.R. \& Daroit, D.J. 2019. Feather hydrolysate as a promising nitrogenrich fertilizer for greenhouse lettuce cultivation. International Journal of Recycling of Organic Waste in Agriculture 8:493-499. https://doi.org/10.1007/s40093-019-0281-7

Stiborova, H., Branska, B., Vesela, T., Lovecka, P., Stranska, M., Hajslova, J., Jiru, M., Patakova, P. \& Demnerova, K. 2016. Transformation of raw feather waste into digestible peptides and amino acids. Journal of Chemical Technology \& Biotechnology 61: 1629-1637. https://doi.org/10.1002/jctb.4912

Tang, X., Placella, S.A., Daydé, F., Bernard, L., Robin, A., Journet, E.-P., Justes, E. \& Hinsinger, P. 2016. Phosphorus availability and microbial community in the rhizosphere of intercropped cereal and legume along a P-fertilizer gradient. Plant Soil 407: 119-134. https://doi.org/10.1007/s11104-016-2949-3

Tejada, M., Rodrígez-Morgado, B., Paneque, P. \& Parrado, J. 2018. Effects of foliar fertilization of a biostimulant obtained from chicken feathers on maize yield. European Journal of Agronomy 96: 54-59. https://doi.org/10.1016/j.eja.2018.03.003

Thatcher, L.F., Gao, L.-L. \& Singh, K.B. 2016. Jasmonate Signalling and Defence Responses in the Model Legume Medicago truncatula-A Focus on Responses to Fusarium Wilt Disease. Plants 5. https://doi.org/10.3390/plants5010011

Thompson, J.P. 1987. Decline of vesicular-arbuscular mycorrhizae in long fallow disorder of field crops and its expression in phosphorus deficiency of sunflower. Australian Journal of Agricultural Research 38: 847-867. https://doi.org/10.1071/AR9870847

van den Berg, C.G.J. \& Rossnagel, B.G. 1990. Effects of temperature and leaf wetness period on conidium germination and infection of barley by Pyrenophora teres. Canadian Journal of Plant Pathology 12: 263-266. https://doi.org/10.1080/07060669009500997 


\section{AGRICULTURAL AND FOOD SCIENCE}

Veresoglou, S.D. \& Rillig, M.C. 2012. Suppression of fungal and nematode plant pathogens through arbuscular mycorrhizal fungi. Biology Letters 8: 214-217. https://doi.org/10.1098/rsbl.2011.0874

Vosátka, M., Látr, A., Gianinazzi, S. \& Albrechtová, J. 2012. Development of arbuscular mycorrhizal biotechnology and industry: current achievements and bottlenecks. Symbiosis 58: 29-37. https://doi.org/10.1007/s13199-012-0208-9

Wellburn, A.R. 1994. The spectral determination of chlorophylls a and b, as well as total carotenoids, using various solvents with spectrophotometers of different resolution. Journal of Plant Physiology 44: 307-313. https://doi.org/10.1016/S0176-1617(11)81192-2

Zadoks, J.C., Chang, T.T. \& Konzak, A. 1974. A decimal code for the growth stages of cereals. Weed Research 14: 415-421. https://doi.org/10.1111/j.1365-3180.1974.tb01084.x 